\title{
Electrochemical Remediation of Phthalocyanine Dye Wastewater and simultaneous Hydrogen Production
}

\author{
Konstantinos Dermentzis*, Kokkoni Karakosta, Ramonna Kosheleva and Nikolaos Kokkinos \\ Department of Chemistry, International Hellenic University, 65404 Agios Loucas, Kavala, Greece, \\ Hephaestus Advanced Research Laboratory, International Hellenic University, 65404 Agios Loucas, Kavala, Greece
}

Received 19 September 2020; Accepted 16 December 2020

\begin{abstract}
In this work a continuously operated electrocoagulation process with sacrificial aluminum electrodes is presented for decolorization of aqueous solution containing nickel phthalocyanine reactive dye and simultaneous production of electrolytic hydrogen. The electrocoagulator is equipped with a gas separation tank for harvesting the electrochemically generated hydrogen gas at the cathode. Hydrogen, compared to common fossil fuels, is a clean alternative fuel of high caloric value and zero emission. The need for hydrogen has been increasing rapidly. In recent years, a major concern is to obtain hydrogen and energy from waste and industrial effluents by using them as an energy source. Electrocoagulation has proved to combine efficient removal of pollutants, such as recalcitrant dyes from wastewaters and simultaneously production of hydrogen gas at the cathode. The influence of all operating parameters on the dye removal efficiency and hydrogen production, such as wastewater $\mathrm{pH}$, conductivity, current density, and inlet flow rate were investigated.Experimental results showed that the quality of the treated wastewater was very satisfactory. By working at the optimal parameters i.e. initial pH 8 and current density $10 \mathrm{~mA} / \mathrm{cm}^{2}$, the dye was completely removed (>99.9\%). The energy yield via the harvested hydrogen amounted to $12.5 \%$ of the electrical energy needed for running the electrocoagulation process.
\end{abstract}

Keywords: Batch and continuous process; electrocoagulation; electrolytic hydrogen; phthalocyanine dye

\section{Introduction}

Enormous amounts of water are consumed during dyeing and finishing operations. It is estimated that about 1000 $\mathrm{m}^{3} /$ day of wastewater are produced by a medium-scale textile factory. Dye-house effluents are environmentally toxic since they contain stable compounds showing enhanced resistance to conventional biological treatment and furthermore being suspected to cause carcinogenesis. During the dying procedure more than $40 \%$ of the dyes are not fixed to the textile fibres, which result in the rinse water and are discharged into the receiving water bodies more or less without treatment [1-3]. Beyond high toxicity and low biodegradability, residual dyestuffs in dyehouse effluents exhibit also an aesthetic pollution as dyestuffs are visible even at low concentrations.

Phthalocyanine is a mocrocyclic aromatic compound comprised of four iso-indole molecules bound with nitrogen atom bridges. The most representative metallic complexes are the nickel phthalocyanine (Ni-pc) and the copper phthalocyanine $(\mathrm{Cu}-\mathrm{pc})$ complexes, which are used as dyes and pigments.

Various physical and chemical methods have been applied for decolorization and abatement of dye containing wastewaters, such as coagulation-flocculation [4], adsorption [5], ultra-filtration [6], advanced oxidation [7,8] and electrochemical treatment processes.

Electrochemical processes are viable alternatives for

*E-mail address: koderm@chem.ihu.g

ISSN: 1791-2377 @ 2020 School of Science, IHU. All rights reserved. doi:10.25103/jestr.136.04 successful treatment of recalcitrant pollutants and are mainly based on anodic oxidation at dimensionally stable electrodes $[9,10]$ and electrocoagulation with corrodible iron and/or aluminum electrodes [11-16].

Electrochemical methods exhibit a series of advantages, such as compact equipment, immobilization of the catalyst/electrode, no generation of secondary pollution and easy control of the voltage-current variables facilitating automation of the process.

The electrocoagulation process produces metallic hydroxide flocs by electrodissolution of corrodible anodes, such as iron or aluminum. When aluminum electrodes are used the products are $\mathrm{Al}^{3+}$ ions at the anode and $\mathrm{OH}^{-}$ions as well $\mathrm{H}_{2}$ at the cathode according the equations (1) and (2):

$$
\begin{aligned}
& \mathrm{Al} \rightarrow \mathrm{Al}^{3+}+3 \mathrm{e}^{-} \quad \text { (anode) } \\
& 2 \mathrm{H}_{2} \mathrm{O}+2 \mathrm{e}^{-} \rightarrow 2 \mathrm{OH}^{-}+\mathrm{H}_{2} \quad \text { (cathode) }
\end{aligned}
$$

The produced $\mathrm{Al}^{3+}$ and $\mathrm{OH}^{-}$ions combine to a series of cationic and anionic monomeric or polymeric species, such as $\mathrm{Al}(\mathrm{OH})^{2+}, \mathrm{Al}(\mathrm{OH})_{2}{ }^{+}, \mathrm{Al}_{2}(\mathrm{OH})_{2}{ }^{4+}, \mathrm{Al}(\mathrm{OH})^{4-}, \mathrm{Al}_{6}(\mathrm{OH})_{15}{ }^{3+}$, $\mathrm{Al}_{7}(\mathrm{OH})_{17}{ }^{4+}, \quad \mathrm{Al}_{8}(\mathrm{OH})_{20}{ }^{7+}, \quad \mathrm{Al}_{13} \mathrm{O}_{4}(\mathrm{OH})_{24}{ }^{7+}, \quad \mathrm{Al}_{13}(\mathrm{OH})_{34}{ }^{5+}$ resulting in the formation of the gelatinous coagulant $\mathrm{Al}(\mathrm{OH})_{3}$.

During electrocoagulation many processes occur simultaneously: anodic oxidation, cathodic reduction, particle charge neutralization/flocculation/agglomeration, adsorption by the coagulants and flotation by the hydrogen bubbles. All these processes act synergistically leading to a 
quick removal of various organic and inorganic pollutants from the processed wastewater [17].

Hydrogen of high quality can be harvested, when the electrocoagulation reactor is equipped with a suitable gas separation tank in form of an up-flow anaerobic sludge bed. Hydrogen as an energy source reduces markedly the energy consumption of the electrocoagulation process. Furthermore, it can be used as reactant for various industrial applications. Phalakornkule et al., [18] reported successful electrocoagulation treatment of Reactive Blue 140 and Direct Red 23 dye containing wastewater achieving removal of color $(99 \%)$, COD (93\%) and TS $(89 \%)$, whereas the energy yield via the electrolytic hydrogen production ranged between 8.5 and $13 \%$ of the energy demand for the electrocoagulation process. Deghles and Kurt [19] studied the hydrogen production during the electrocoagulation treatment of tannery wastewater reporting $16 \%$ energy yield and high quality of the treated wastewater with removal of 73, 94, 100 and $51 \%$ for $\mathrm{COD}$, color, $\mathrm{Cr}$ and $\mathrm{NH}_{3}-\mathrm{N}$ respectively.

In the present paper a batch and continuously operated electrocoagulation process with corrodible aluminum electrodes is reported. The process combines the production of high quality treated wastewater and simultaneous energy harvesting via the recovery of the electrolytic hydrogen gas at the cathode.

\section{Materials and methods}

\subsection{Chemicals}

Commercial grade nickel phthalocyanine dye purchased from Aldrich (CAS Nr: 27835-99-0) was used for all studies. Sample dye solutions of $100 \mathrm{mg} / \mathrm{L}$ were used for all experiments. $\mathrm{H}_{2} \mathrm{SO}_{4}, \mathrm{NaOH}, \mathrm{NaCl}$ and $\mathrm{Na}_{2} \mathrm{SO}_{4}$ of analytical grade were purchased from Merck. The required $\mathrm{pH}$ value was adjusted using $0.1 \mathrm{M}$ solutions of $\mathrm{H}_{2} \mathrm{SO}_{4}$ and $\mathrm{NaOH}$. Figure 1 shows the structure of Ni-pc dyestuff.

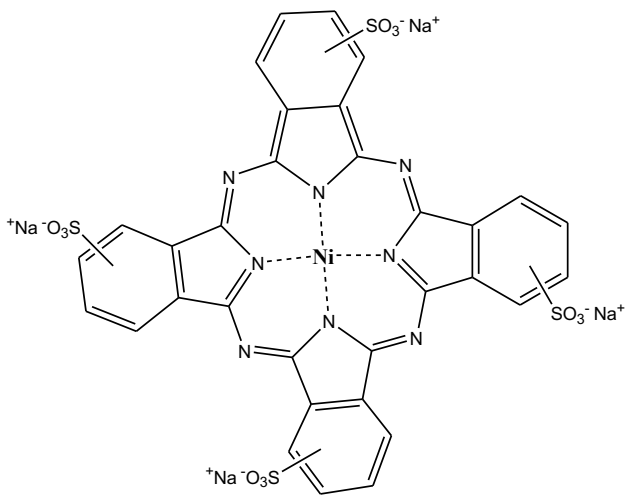

Fig. 1. Chemical structure of the reactive dye nickel phthalocyanine tetrasulfonic acid tetrasodium salt (Ni-pc), Mr: 979.40, Linear Formula: $\mathrm{C}_{32} \mathrm{H}_{12} \mathrm{~N}_{8} \mathrm{Na}_{4} \mathrm{NiO}_{12} \mathrm{~S}_{4}$

\subsection{Apparatus}

Agilent (E3612A, USA) was used as a power supply apparatus to measure the applied current and voltage. Conductometer (WTW) and pH-meter (WTW) were used for measuring the corresponding conductivity and $\mathrm{pH}$ of the treated solution.

\subsection{Electrochemical cell}

The batch experiments were carried out at room temperature in a cylindrical acrylic reactor containing $400 \mathrm{~mL}$ of wastewater, which was slowly stirred at $500 \mathrm{rpm}$. Two aluminum grid anodes and one central aluminum plate cathode, each with dimensions $10 \mathrm{~cm} \times 5 \mathrm{~cm} \times 0.2 \mathrm{~cm}$, immersed to a $6 \mathrm{~cm}$ depth with an effective area $30 \mathrm{~cm}^{2}$, served as corrodible electrodes. The distance between the electrodes was adjusted to $2 \mathrm{~cm}$.

The continuous electrocoagulation experiments were conducted in a similar however, larger self made flowthrough reactor containing $2 \mathrm{~L}$ of wastewater, three larger $\mathrm{Al}$ electrodes $(20 \mathrm{~cm} \times 10 \mathrm{~cm} \times 0.2 \mathrm{~cm})$ immersed to a $15 \mathrm{~cm}$ depth with an effective area $150 \mathrm{~cm}^{2}$. The continuous flowthrough reactor was furthermore equipped with a peristaltic pump, a flow meter, a gas collector and a gas flow meter above the central cathode to collect and measure the electrochemically generated hydrogen gas as illustrated in Figure 2:

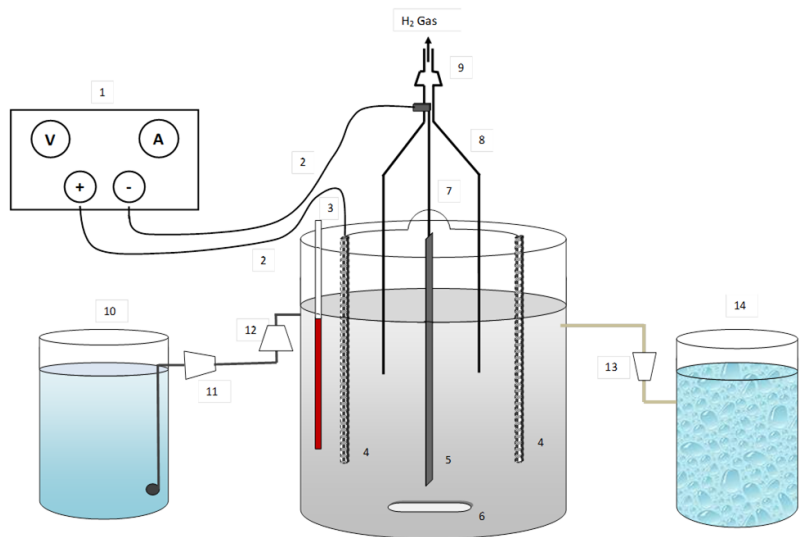

Fig. 2. Continuous electrocoagulation reactor set up (1)Power supply, (2) cables, (3) thermometer, (4) anodes, (5) cathode, (6) stirring fish, (7) cable connecting the anodes, (8) gas separator, (9) gas flow meter, (10) wastewater deposit, (11) peristaltic pump, (12) flow meter, (13) filter, (14) treated solution

\subsection{Analytical Procedure}

The spectroscopic determination of the phthalocyanine dye concentrations was followed and analyzed by UV-VIS Spectrophotometry (HITACHI U-2000, Japan). Samples were brought to analysis after filtration with polytetrafluorethylene filters of $0.45 \mu \mathrm{m}$ pore size (Whatman). The supporting electrolyte was $\mathrm{NaCl}$. For reproducibility all measurements were conducted in duplicate. Experiments for both, batch and continuous mode of operation were performed.

For calculation of the percent removal efficiency of dye $(\% \mathrm{R})$ was served equation (3):

$\% \mathbf{R}=\frac{\mathbf{C}_{\mathbf{0}-} \mathbf{C}_{\mathbf{t}}}{\mathbf{C}_{\mathbf{0}}} \mathbf{x 1 0 0}$

where $\mathrm{C}_{\mathrm{o}}$ is the initial dye concentration and $\mathrm{C}_{\mathrm{t}}$ at time $\mathrm{t}$.

\section{Results and Discussion}

\subsection{Batch wise operated treatment}

Various batch experiments were carried out to investigate the parameters affecting the dye removal efficiency and find optimal conditions for the electrocoagulation treatment of the wastewater samples.

\subsubsection{Effect of solution $\mathrm{pH}$}

The initial $\mathrm{pH}$ value plays a significant role on the efficiency of an electrochemically treated solution. In order to show this dependence, the aqueous dye solution of various initial 
pHs $(2,4,6,8,10,12)$ was tested at the same constant current density $10 \mathrm{~mA} / \mathrm{cm}^{2}$, room temperature $25{ }^{\circ} \mathrm{C}$, same solution volume $400 \mathrm{~mL}$ and same dye concentration 100 $\mathrm{mg} / \mathrm{L}$.

Figure 3 shows that optimal solution $\mathrm{pH}$ for dye removal during the electrocoagulation treatment is the near neutral region between $\mathrm{pH} 6$ and 8 displaying almost quantitative removal $(>99 \%)$. The removal percentage is very low at $\mathrm{pH}<2$. It increases significantly at $\mathrm{pH} 4$, remains high and almost constant between $\mathrm{pH} 6$ to 10 and slightly decreases at higher alkaline $\mathrm{pH}$ values.

Adhoum et al. [20] and Vasuderan et al. [21] have studied the reduction of the removal efficiency in both, strong acidic and strong alkaline media. They explained it due to the amphoteric behavior of $\mathrm{Al}(\mathrm{OH})_{3}$ that forms soluble $\mathrm{Al}^{3+}$ cations in acidic and soluble $\mathrm{Al}(\mathrm{OH})_{4}{ }^{-}$anions in basic $\mathrm{pH}$. These species are less stronger coagulating agents than $\mathrm{Al}(\mathrm{OH})_{3}$ and, therefore, less suitable for wastewater treatment by electrocoagulation.

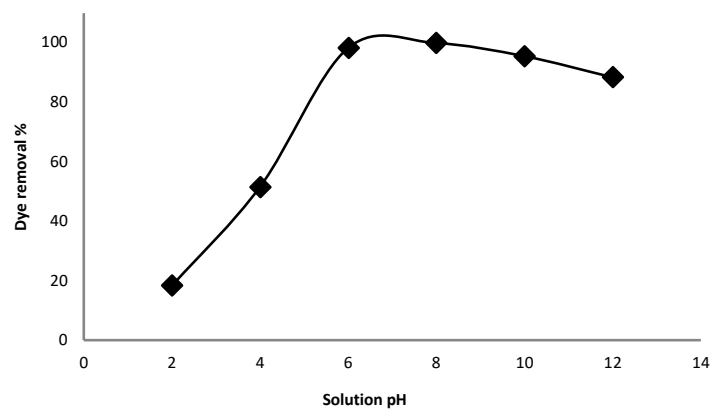

Fig. 3. Dye removal percent versus various initial solution $\mathrm{pHs}$.

\subsubsection{Effect of applied current density}

According to the findings of Khosla et al. [22] and our previous work [23] the applied current density is a very important determining factor affecting immediately the rate of coagulant dosage, the production of $\mathrm{H}_{2}$ bubbles and the growth and size of flocs leading to faster removal of pollutants. Electrocoagulation experiments were carried out at various current densities 5,10 and $20 \mathrm{~mA} / \mathrm{cm}^{2}$, using the same initial Ni-pc concentration $100 \mathrm{mg} / \mathrm{L}$ and optimal solution $\mathrm{pH} 8$. According to Figure 4, the removal rates of dye increased, as anticipated, with increasing applied current density. Namely, complete dye removal $(>99.9 \%)$ occurred in 10, 6 and 4 minutes of electroprocessing time using current densities 5,10 and $20 \mathrm{~mA} / \mathrm{cm}^{2}$ respectively.

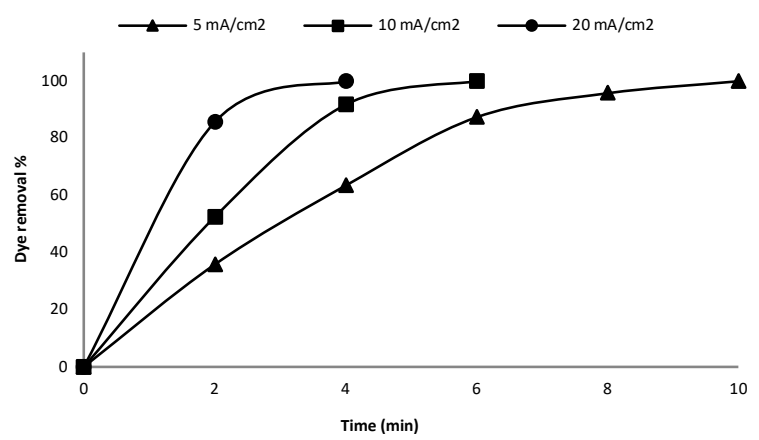

Fig. 4. Removal percentage of Ni-pc dye with time for various applied current densities

\subsubsection{Effect of initial Ni-pc dye concentration}

Experiments were conducted with different initial concentrations of the Ni-pc dye, keeping constant the applied current density at $10 \mathrm{~mA} / \mathrm{cm}^{2}$, constant initial $\mathrm{pH} 8$ and different electroprocessing time. According to Figure 5 the corresponding complete reduction of the initial due concentrations of 50,100 and $150 \mathrm{mg} / \mathrm{L}$ appeared in 4,6 and 10 minutes of electroprocessing time. The electrocoagulation treatment of solutions with higher initial dye concentrations certainly needs more electroprocessing time, however, the removal rate is higher than by lower concentrations. This is indicated by the abrupt change of the dye concentration at the beginning where the dye concentration is high than at the end where the dye concentration is low.

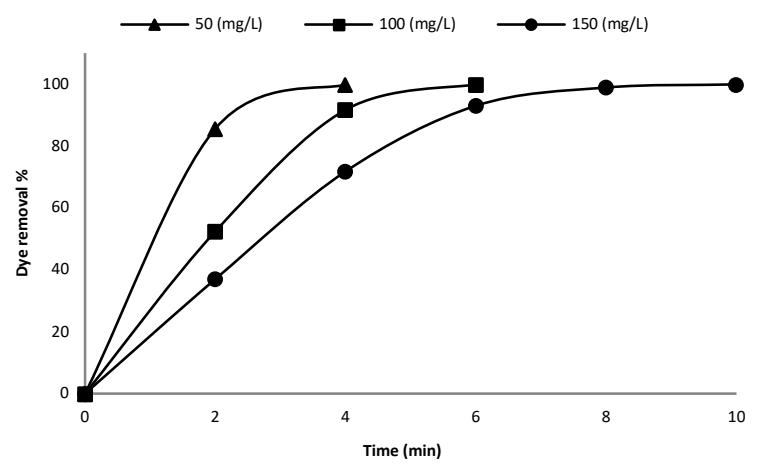

Fig. 5. Dye removal percentage versus time for various initial dye concentrations

\subsection{Continuously operated treatment}

The efficiency of the continuous electrocoagulation process is influenced by the same parameters as the batch wise operated process and additionally by the inlet flow rate, the wastewater conductivity and the residence time. Consequently, the investigated optimal affecting parameters pH 8 and applied current density $10 \mathrm{~mA} / \mathrm{cm}^{2}$ were used for the continuously operated experiments.

\subsubsection{Effect of inlet flow rate}

High flow rates accelerate the electrocoagulation process but reduce the residence time and influence, therefore, the dye concentration in outlet wastewater stream. The inlet flow rate of treated wastewater was increased from 15, 30, 45, 60, 75 to $90 \mathrm{~mL} / \mathrm{min}$ respectively, keeping constant the current density at $10 \mathrm{~mA} / \mathrm{cm}^{2}, \mathrm{pH} 8$ and room temperature $25{ }^{\circ} \mathrm{C}$. As illustrated in Figure 6, the dye removal percent in the outlet stream remains initially very high ( $>99 \%$ ) for the low flow rates $(15-45 \mathrm{~mL} / \mathrm{min})$ and as the flow rate further increases (60 to $90 \mathrm{~mL} / \mathrm{min}$ ), it begins to drop from $>99$ to about $71 \%$, whereas the residual outlet dye concentration begins to rise from 0 to $29 \mathrm{mg} / \mathrm{L}$.

\subsection{Eletrolytic hydrogen production}

The electrochemical treatment of aqueous organic waste can be coupled with hydrogen production. The organic matter facilitates the electrochemical splitting of water by producing $\mathrm{H}^{+}$ions and electrons at the anode and electrolytic $\mathrm{H}_{2}$ gas at the cathode $[18,19,24,25]$. The energy harvesting via the produced hydrogen gas is calculated from equation (4):

$\mathrm{E}_{H 2}=\mathrm{m}_{H 2} \times 122 \mathrm{~kJ} / \mathrm{g}_{H 2}$

where $\boldsymbol{m}$ is the mass of produced hydrogen and $122 \mathrm{~kJ}$ is the specific heat per $g$ of hydrogen. 


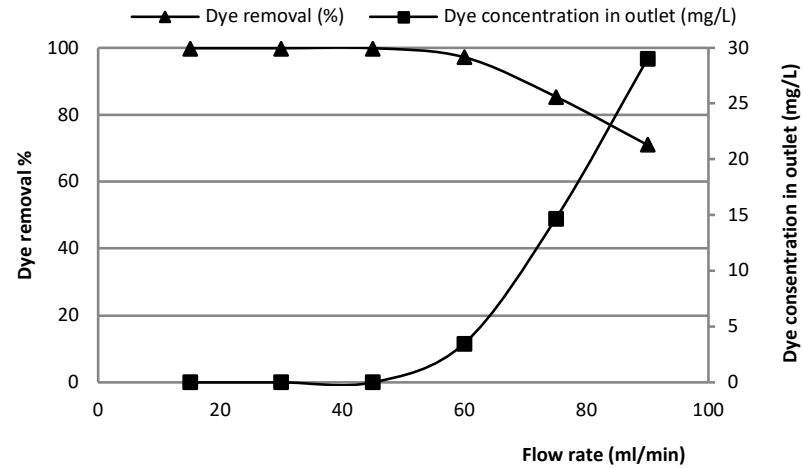

Fig. 6. Concentration and removal percent of Ni-pc dye in outlet stream versus inlet flow rate

Thus, during the continuous electrochemical treatment of the Ni-pc dye wastewater at the inlet flow rate $60 \mathrm{~mL} / \mathrm{min}$ and current density $10 \mathrm{~mA} / \mathrm{cm}^{2}$, about $175 \mathrm{~L}$ hydrogen gas per $\mathrm{m}^{3}$ of treated wastewater can be produced, which corresponds to $12.5 \%$ energy recovery. In this way, the electrocoagulation process offers a double objective, namely wastewater remediation and energy recovery.

\section{Conclusions}

A batch and continuously operated electrocoagulation process with aluminum electrodes has been reported and the affecting parameters investigated. The continuous mode with inlet flow rate $60 \mathrm{~mL} / \mathrm{min}$, applied current density 10 $\mathrm{mA} / \mathrm{cm}^{2}$ and solution $\mathrm{pH} 8$ led to complete decolorization and removal of the nickel phthalocyanine dye by $>99.9 \%$ and simultaneously $175 \mathrm{~L}$ hydrogen per $\mathrm{m}^{3}$ of treated dye solution was harvested. The energy yield via the recovered $\mathrm{H}_{2}$ gas was $12.5 \%$ of the electrical energy required for running the electrocoagulation process. Thus, taking into account the significant decrease of the electrical energy demand via the hydrogen utilization and the quantitative dye removal from treated wastewater, electrocoagulation could be regarded as a useful technology for both, environmental clean-up and energy harvesting.

This is an Open Access article distributed under the terms of the Creative Commons Attribution License

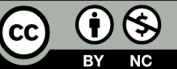

\section{References}

1. Berradi M., Hsissou R., Khudhair M., Assouag M., Cherkaoui O., El Bachire A., El Harfi A., Textile finishing dyes and their impact on aquatic environs, Heliyon 5 (2019), e02711.

2. Kant R., Textile dying industry an environmental hazard, Natural Sci. 4 (2012) 22-26.

3. Khalil E., Sarkar J., Effect of hardness on water fixation and total wash off percentage of reactive dyes when applied to cellulosic fiber, Int. J. Sci. Res. Publ., 4, 9, ISSN 2250-3151.

4. Rodrigues C.S.D., Madeira L.M., Boaventura R.A.R., Treatment of textile dye wastewaters using ferrous sukphate in a chemical coagulation/flocculation process, Environ. Technol. 34 (2013) 719729.

5. Kyzas G.Z., Christodoulou E., Bikiaris D.N., Basic dye removal with sorption onto low-cost natural textile fibers, Processes 6 (2018) 166 doi:10.3390/pr6090166.

6. Lafi R., Gzara L., Lajimi R.H., Hafiane A., Treatment of textile wastewater by a hybrid ultrafiltration/electrodialysis process, Chem. Eng. Proc.-Proc. Int. 132 (2018) 105-113.

7. Guimaraes J.R., Maniero M.G., Nogueira de Araujo R., A comparative study on RB-19 dye in an aqueous medium by advanced oxidation processes, J. Environ. Manage. 110 (2012) 3339.

8. Turhan K., Durukan I., Ozturkcan S.A., Turgut Z., Decolorization of textile basic dye in aqueous solution by ozone, Dyes Pigments 92 (2012) 897-891.

9. Tsantaki E., Velegraki T., Katsaounis A., Mantzavinos D., Anodic oxidation of textile dyehouse effluents on boron-doped diamond electrode, J. Haz. Mat. 207-208 (2011) 91-96.

10. Zeng Y.M., Yunus R.F., Nanayakkara K.G.N. Chen J.P., Electrochemical decolorization of synthetic wastewater containing Rhodamine 6G: Behaviors and mechanism, Ind. Eng. Chem. Res. 51,17 (2012) 5953-5960.

11. Khadegar V., Saroha A.K., Electrocoagulation for the treatment of textile industry effluent-a review, J.Environ. Manage. 128 (2013) 949-963.

12. Amour A., Merzouk B., Leclerc J-P., Lapicque F., Removal of reactive textile dye from aqueous solutions by electrocoagulation in a continuous cell, Desalination Water Treat. 57 (2016) 2276422773.

13. Secula M.S., Cretescu I., Petrescu S., An experimental study of indigo carmine removal from aqueous solution by electrocoagulation, Desalination 277, (2011) 227-235
14. Aygun A., Nas B., Sevimli M.F., Treatment of reactive dye wastewater by electrocoagulation process: Optimization of costestimation, Korean J. Chem. Eng., 36 (2019) 1441-1449.

15. Stylianou M., Montel E., Dermentzis K., Agapiou A., Electrochemical treatment of cattle wastewater samples, Biomass Waste Valor., doi.org/10.1007/s12649-020-01056-8.

16. Marmanis D., Dermentzis K., Christoforidis A., Moumtzakis A., Electrochemical decolorization of actual textile dye effluents by electrocoagulation process directly powered by photovoltaic energy, Desalination and Water Treatment, 56, (2015) 2988-2993.

17. Kobya M., Can O.T., Bayramoglu M., Treatment of textile wastewaters by electrocoagulation using iron and aluminium electrodes, J. Hazard. Mater. 100 (2003) 163-178.

18. Phalakornkule C., Sukkasem P., Mutchimsattha C., Hydrogen recovery from the electrocoagulation treatment of dye-containing wastewater, Int. J. Hydrogen Energy, 352010 10936-10943.

19. Deghles A. and Kurt U., Hydrogen gas production from tannery wastewater by electrocoagulation of a continuous mode with simultaneous pollutants removal, IOSP J. Appl. Chem. 10 (2017) 40-50.

20. Adhoum N., Monser L., Bellakhal N., Belgaied J-E., Treatment of electroplating wastewater containing $\mathrm{Cu}^{2+}, \mathrm{Zn}^{2+}$ and $\mathrm{Cr}(\mathrm{VI})$ by electrocoagulation, J. Hazard. Mater. B112 207-213 (2004).

21. Vasudevan S., Lakshmi J., Sozhan G., Studies on the removal of iron from drinking water by electrocoagulation-A clean process, Clean: Soil, Air, Water 37 45-51 (2009).

22. Koshla N.K., Venkachalam S. and Sonrasundaram P. (1991), Pulsed electrogeneration of bubbles for electroflotation, Journal of Applied Electrochemistry, 21, 986-990.

23. Dermentzis K., Marmanis D., Valsamidou E., Christoforidis A. Ouzounis K., Electrochemical decolorization treatment of nickel phthalocyanine reactive dye from wastewater, Environ Engin. Manage J. 10 (2011) 1703-1709.

24. Kargi F., Uzuncar S., Simultaneous Hydrogen gas formation and COD removal from cheese whey wastewater by electrohydrolysis, Int. J. Hydrogen Energy 37 (2012) 11656- 11965.

25. Eker S., Kargi F., Hydrogen gas production from electrohydrolysis of industrial wastewater organics by using photovoltaic cells, Int. J. hydrogen Energy 35 (2010) 12761-12766. 